\title{
Investigating the Impacts of Individual Traits and Product Characteristics on Customer Evaluation of Sweepstakes
}

\author{
Yukihiro Miwa ${ }^{1}$, Makoto Morisada ${ }^{1}$ \& Wirawan D. Dahana ${ }^{1}$ \\ ${ }^{1}$ Gradute School of Economics, Osaka University, Japan \\ Correspondence: Wirawan D. Dahana, Graduate School of Economics, Osaka University, Toyonaka, Osaka, \\ Japan. Tel: 81-6-6850-5241. E-mail: dony@econ.osaka-u.ac.jp
}

Received: August 20, $2017 \quad$ Accepted: September 12, $2017 \quad$ Online Published: September 30, 2017

doi:10.5539/ijms.v9n5p1 URL: http://doi.org/10.5539/ijms.v9n5p1

\begin{abstract}
This study investigates the effects of individual traits and products characteristics on customer evaluation of sweepstakes promoted by retail firms. We assume that customer's preference toward sweepstakes is determined by four primary attributes: implementation term, entry condition, prize size, and winning odds. The importance customers attach to these attributes are proposed to be influenced by the extent of rationality, regret, and store loyalty. Further, we explore how the evaluations are moderated by the type of product category (goods vs. service) and product involvement (low vs. high). The results from a conjoint analysis and a multivariate regression analysis applied to ordered-preference data show that rationality and behavioral loyalty have significant effects on the importance attached to implementation term, prize size, and winning odds. Further, the results also reveal that attitudinal loyalty play a significant role in the evaluation of low involvement products, while rationality and behavioral loyalty appear to be influential for high involvement products. These results provide new insights into the interplays among sweepstakes attributes, individual traits, and products characteristics as well as managerial implications for retailers developing a loyalty program strategy.
\end{abstract}

Keywords: sweepstakes, loyalty programs, individual traits, conjoint analysis, customer relationships

\section{Introduction}

Many firms have realized that nurturing and maintaining customer relationship are critical to increase long-term profitability (Kumar \& Reinartz, 2012). It has been common practice that firms invest considerable amounts to track and strengthen customer relationships (Rigby \& Ledingham, 2004). To maintain good relationships with their customers, firms need to build customer loyalty by creating satisfactory shopping experiences (Bolton, Kannan, \& Bramlett, 2000). Studies have shown that customer loyalty can be strengthened through the implementation of customer loyalty programs (Uncles, Dowling, \& Hammond, 2003; Lewis, 2004; Kumar \& Shah, 2004). According to Blattberg, Kim, \& Neslin (2008), effective loyalty programs can induce customers to purchase more frequently and prevent them from churning; and thus, increase customer lifetime value. For this reason, how firms should design loyalty programs to attract many customers to participate and eventually enhance their purchasing behavior has been a central issue in the research field (Dowling \& Uncles, 1997; Sharp \& Sharp, 1997; Roehm, Pullins, \& Roehm, 2002).

In practice, the implementation of loyalty programs are undertaken by using various non-price promotions such as airline mileages, retailer point cards, instant scratches, and sweepstakes (Dowling \& Uncles, 1997; Yi \& Jeon, 2003). In this study, we focus on sweepstakes, a non-price promotional tool that has been widely adopted by marketers to increase purchase frequency or brand awareness of their customers. According to Kalra \& Shi (2010), about $10 \%$ of marketers allocated a considerable budget on sweepstakes, and the total amount invested was projected to increase every year. However, despite the wide adoption of sweepstakes, research study related to this issue is still sparse. Few studies have attempted to elucidate the effects of demographic, socioeconomic, and psychographic characteristics on consumer decision to enter sweepstakes (Narayana \& Raju, 1985; Huff \& Alden, 1999; McDaniel, 2002), but how the decisions are affected by various attributes constituting sweepstakes has remained unexplored. In fact, Kalra \& Shi (2010) provided evidence that consumer valuations of sweepstakes are attributable to the number of winners and the allocation of the reward. However, they did not account for potential influence of other attributes such as implementation term and entry conditions, which play pivotal roles in the design of loyalty programs (Kivetz \& Simonson, 2002; Malhotra, Loewenstein, \& 
O'Donoghue, 2002). In addition, while prior studies have shown that consumer response to price promotions varies depending on the characteristics of the promoted products (Wakefield \& Barnes, 1996; Hunt, Keaveney, \& Lee, 1995), how sweepstakes evaluation is influenced by product characteristics has not been addressed in the literature.

In this study, we aim to fill the gap in the literature by examining how customer evaluation of sweepstakes is determined by the importance attached to several sweepstakes attributes. Here, we extend the work of Kalra \& Shi (2010) by considering the tradeoff among four attributes: implementation term, entry condition, size of prize, and winning odds. Further, to account for customer heterogeneity, we proposed a framework in which the evaluation varies depending on the extent of four individual traits: rationality, regret, behavioral loyalty, and attitudinal loyalty. In addition, we examine potential differences of the evaluations across product categories according to product type (goods vs. service) and product involvement (low vs. high).

Based on the literature, we build relevant hypotheses and empirically test them using ordered-preference data collected in a survey. Sweepstakes evaluations are assessed by estimating the individual-level part-worth utility for each attribute in a conjoint analysis. Subsequently, we conduct a multivariate regression analysis to link the ranges of the part-worth utilities to individual traits of interest. To examine the potential effects of product characteristics, the analysis are conducted separately for different product categories. The results reveal that average customers perceive winning odds as the most important attribute, followed by entry condition, prize size, and implementation term. However, the evaluations appeared to be influenced by individual traits and product characteristics.

The main contributions of this study are twofold. First, it provides new insights into how customer rationality, regret, and store loyalty affect the importance attached by customer to each sweepstakes attribute, and eventually affect the evaluation of the sweepstakes. Further, exploring the effect of product characteristics, this study provides empirical evidence of how the evaluation varies across product categories. Second, the analysis derives managerial implications that are important for marketers to design effective sweepstakes as well as to better target the promotions.

We organize the remainder of this article as follows. In the next section, we highlight the concept of sweepstake as a tool of loyalty programs along with its key attributes. Subsequently, we describe the analysis framework and provide the research hypotheses. We then illustrate the research methodology and the data used in the analysis. Following these sections, we show the estimation and hypothesis testing results and discuss the implications. Finally, we conclude this article with several limitations and directions for future research.

\section{Theoretical Background}

\subsection{Loyalty Programs}

A loyalty program can be defined as a marketing practice conducted by a firm to build and enhance customer relationship by offering profitable customers incentives to repurchase (Yi \& Jeon, 2003). Its main objective is to improve loyalty by rewarding customers who purchase up to a required volume from the firm (Bolton et al., 2000). In practice, there are several types of loyalty program such as airline mileages, retailer point cards, sweepstakes, and contests. Dowling \& Uncles (1997) classified loyalty program into for types based on whether the reward supports the product/service value proposition (direct or indirect) and when the reward is available (immediate or delayed). A direct loyalty program pertains to the one in which the reward is strongly linked to the promoted product or service; thus, it is considered to have immediate effects on customer loyalty. Examples of direct loyalty program are coupons and frequent flyer programs. By contrast, indirect loyalty programs provide participants with a reward that is not directly associated with the product or services. Competitions, lotteries, and multi-product frequent-buyer clubs are examples of this category.

Blattberg et al. (2008) suggested that loyalty programs may increase customer value because it can increase purchase frequency and retention rate of customers who join the program. The authors argued that the positive impacts of loyalty programs are attributable to three underlying mechanisms: point pressure, rewarded behavior, and personalized marketing. The point pressure arises when customers are motivated to make purchases in order to earn the reward. This effect is even stronger as the customers approach the requirements for a reward. This argument has gained an empirical support from a study by Kivetz, Urminsky, \& Zheng (2006) showing that program participants accelerated their purchases as they got closer to the goal. Rewarded behavior mechanism pertains to an increase in purchase rate after customers receive the reward which is resulted from favorable changes in attitudes toward the firm (Taylor \& Neslin, 2005). The third mechanism, personalized marketing, occurs when purchase and retention rate increase due to individually customized promotion, cross-selling, or customer service efforts targeted at the program members (Blattberg et al., 2008). 
Additionally, Yi \& Jeon (2003) pointed out that loyalty program should be seen as activities involving repeat purchases of product by customers to get the reward; and thus, they argued that price promotion should not be considered as a loyalty program because customers who respond to price promotions are usually those who are price-conscious rather than profitable customers. Moreover, price promotions tend to reduce internal reference price (Mazumdar, Raj, \& Sinha, 2005; Blattberg, Briesch, \& Fox, 1995) and eventually lower customer loyalty as customers become more sensitive to price changes.

\subsection{Sweepstakes}

A sweepstake is a type of loyalty programs that offers prize to some or all of its participants. If only a part of entrants are able to win the prize, lotteries are drawn to decide the winners, distinguishing sweepstakes from contests which require certain level of skill or effort to win (Kalra \& Shi, 2001). It is also different from point programs in that all entrants have the same chance to win regardless of their purchase amounts. In many cases, customers are required to make purchases up to a certain volume to enter sweepstakes, although in some countries there are strict regulations prohibiting such entry condition. Depending on the agent who conducts it, sweepstakes can be classified into manufacturer- and retailer-promoted sweepstakes. The former usually requires customers to buy a particular brand from the manufacturer, whereas the latter requires consumers to purchase up to a certain amount from the store in order to enter.

It is common that sweepstakes are conducted for a predetermined time period; thus, entrants have to wait until the winners are announced and the prizes are delivered. This means that sweepstakes can be classified as delayed loyalty program in Dowling and Uncles' categorization. However, because the type of the prizes may vary depending on the policy of the promoting agent, it can be categorized as either direct or indirect loyalty program. For example, in retailer-promoted sweepstakes, the prizes would be the ones that unrelated to a particular brand because retailers generally sell various products of different manufacturers. By contrast, sweepstakes carried out by service providers such as airline companies or travel agents usually provide prizes that support the main services.

\subsection{The Attractiveness of Sweepstakes}

As a type of loyalty programs, sweepstakes should be designed so that it can attract as many customers as possible to enter. Arguably, customers' participation in a sweepstake will depend largely on their perceptions of its attractiveness, which is determined by its attributes. As suggested by Kalra \& Shi (2001), the size of the prizes and the odds of winning influence consumers' evaluation of sweepstakes' attractiveness. Sweepstakes offering grand prizes should be perceived to be more attractive than those offering small prizes. Higher prize is also effective in inducing purchases of the entrants because of higher point pressure (Blattberg et al., 2008). However, it should be noted that too strong prize may cause customers focus on the reward rather than on the product (Rothchild \& Gaidis, 1981). Further, customers should prefer sweepstakes with higher winning odds to the ones with lower winning odds, ceteris paribus.

Another attribute that should be influential is entry condition. As previously stated, sweepstakes' promotors often require consumers to buy a particular brand or to purchase up to a certain amount in a store as entry conditions. Requiring customers to pay a high amount may create barriers to enter, which eventually reduce consumers' willingness to join (Kivetz \& Simonson, 2002; 2003). In addition, we also expect consumers' evaluation of sweepstakes value to depend on the length of the implementation period. If the delay to get the prize takes a longer time, consumers will discounted the value of the prize (Malhotra et al., 2002), leading to a decline in sweepstakes attractiveness. This is consistent with the finding by Yi \& Jeon (2003) suggesting that perceived value of loyalty programs is greater for immediate rewards than for delayed rewards.

Considering the important roles of these attributes, a marketer may want to know how to determine the level of each attribute so that she/he can entice target customers to enter a sweepstake. Undoubtedly, this decision will depend on sweepstake's objectives, budget constraints, and tradeoff among the attributes. For instance, the size of the prizes and the number of the winners must be decided so that the total costs do not exceed the budget. Moreover, given a fixed budget, increasing the size of the prizes will inevitably cause the promotors to reduce the number of the winners. Further, if sweepstakes is aimed to increase the sales of a brand or a store, setting higher entry conditions would increase purchases made by loyal customers, but may simultaneously prevent the participation of less loyal customers. Additionally, if sweepstakes is conducted in a long time period, the number of consumers who eventually enter should increase; however, this potentially reduces the satisfaction of entering the sweepstakes because of diminishing present value of the prizes. In sum, better understanding how consumers weigh each attribute in evaluating sweepstakes is necessary to design effective sweepstakes. 


\section{Research Framework and Hypotheses}

\subsection{Research Framework}

In this study, we aim to address how individual traits and product characteristics influence the way customers assess the value of retailer-promoted sweepstakes. We focus on Japanese market where it is legal for retailers to require target customers to purchase products from the stores as entry condition. In line with previous studies, we assume that sweepstake's attractiveness is determined based on the evaluation of four attributes: implementation term, entry condition, prize amount, and winning odds. The individual traits that are expected to influence sweepstakes evaluation are rationality, regret, behavioral loyalty, and attitudinal loyalty. The reasoning for choosing these variables, along with the predicted direction of their effects are given in the following subsections. Figure 1 illustrates the conceptual framework of this study.

\subsection{Rationality}

In neo-classical economics, the expected utility theory asserts that rationality plays an important role in consumer decision making (von Neumann \& Morgenstern, 1947; Savage, 1951). That is, rational consumers make a choice decision from a set of alternatives to maximize their expected utility. The theory assumes that consumers have a perfect knowledge about available alternatives and thus are able to predict the outcome resulted from choosing one of them. Schwartz et al. (2002) pointed out that consumers who are highly inclined to maximize their expected utility (termed as maximizers) tend to extensively gather information on the alternatives under consideration. However, this contention has been criticized by researchers in the field of psychology, sociology, and consumer behavior. For example, Alba et al. (1999) argued that consumers may have limited information about the alternatives to be chosen. Further, consumers may not be able to make objective judgment about the consequences of their choice due to some sorts of biases (Arcidiacono, 2011). For this reason, the extent of rationality should vary across consumers, depending on their knowledge about the alternatives and the ability to make accurate evaluation of their outcomes.

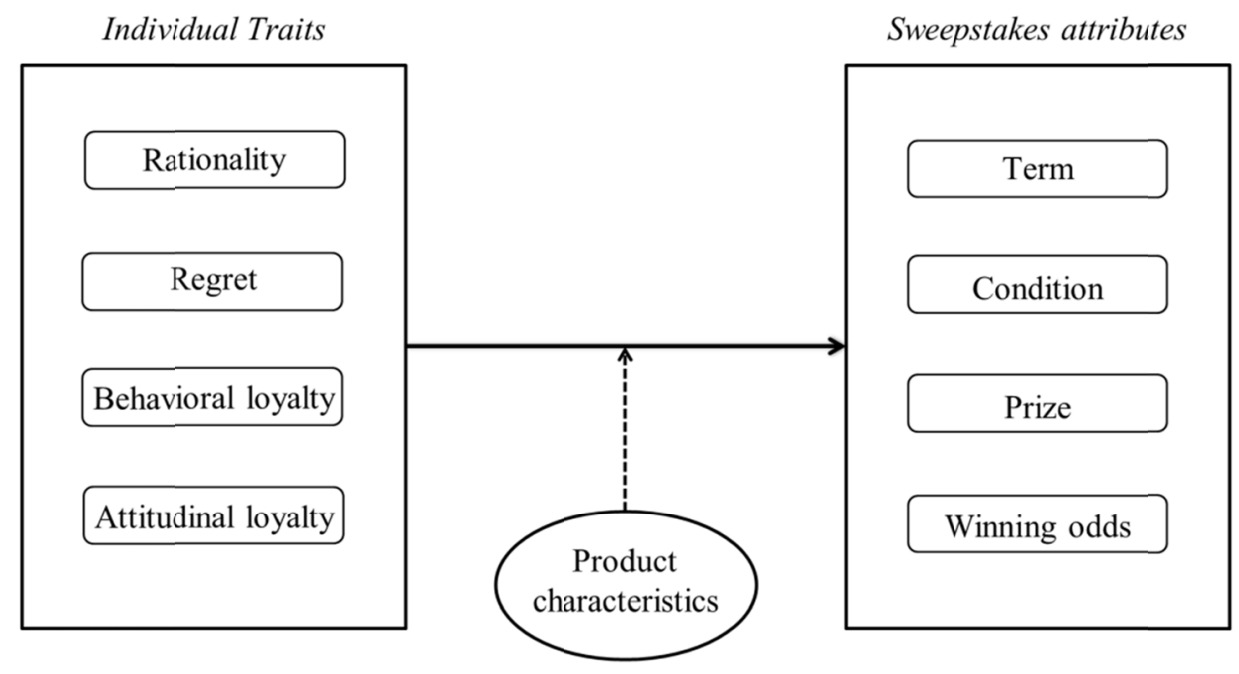

Figure 1. Analytical framework of this study

When assessing the value of sweepstakes, rational customers should have greater motivation to anticipate the discounted value of the prize because they have a great concern with the time value of money (Malhotra et al., 2002). Since the present value of a sweepstake's prize depends on the time at which it is delivered, the length of sweepstakes period should be critical in their evaluation, rendering them to place considerable importance to this attribute. Moreover, as rational customers strive to maximize the expected utility when entering sweepstakes, which depend on all possible outcomes of each alternative along with their probability, the size of the prize and the odds of winning should influence their evaluation as well (Chew \& Tan, 2005). This is consistent with the expectation principle (Kahneman \& Tversky, 1979) and maximum likelihood principle (Kurhade \& Wankhade, 2016) asserting that the expected utility of choosing an alternative depends on all of its possible outcomes and its 
likelihood of occurrence. Thus, higher rationality will lead to greater importance attached on sweepstakes' term and prizes. Hence,

H1: Subjects with higher degree of rationality will attach a greater importance to sweepstakes' (a) term, (b) prize, and (c) winning odds.

\subsection{Regret}

Regret can be defined as comparison-based emotion of self-blame, experienced when people imagine that their current situation would have been better had they made different decisions in the past (Zeelenberg et al., 1998; Zeelenberg \& Pieters, 2007). This feeling arises from a discrepancy between the actual results of chosen alternative and the expected results of forgone alternatives. Inman, Dyer, \& Jia (1997) distinguished regret from disappointment where the latter concerns a comparison between actual and expected performances of the chosen alternative. An individual experiences regret when she/he find that the chosen alternative appears to be less favorable than the forgone one (Tsiros \& Mittal, 2000). Previous studies have shown that regret can result in dissatisfaction (Inman, Dyer, \& Jia, 1997; Taylor, 1997), lower preferences toward a brand (Simonson, 1992), and switching to other alternatives (Tsiros \& Mittal, 2000). Further, studies also indicated that the tendency to experience regret varies across individuals (Bell, 1982; Loomes \& Sugden, 1982). Consumers who are more inclined to regret will evaluate each alternative cautiously to avoid experiencing such a feeling.

In the context of retailer-promoted sweepstakes, customers have to purchase in the store up to a threshold in order to participate. For some people, it may involve multiple shopping trips to meet the condition, causing them forgone shopping opportunities in other stores. Even when they manage to meet the condition and subsequently enter the sweepstakes, the likelihood to get the prizes will depend on the number of entrants. Consequently, there are two outcomes that potentially lead to a regret experience. The first one is the case when customers are unable to participate in sweepstakes because they fail to meet the condition. In this case, regret stems from a greater perceived utility they could have attained should they made purchases in other stores. The second outcome occurs when they fail to win the prize. Similar to the first case, customers experience regret because they perceive the forgone utility from buying in other stores is greater than that from buying in the focal store without winning any prize. This line of reasoning provides a basis for expecting customer heterogeneity in evaluating sweepstakes attractiveness with respect to the difference in regret tendency. Customers who tend to regret would regard entry condition and the odds of winning as important attributes determining the value of sweepstakes. Hence,

H2: Subjects who are more inclined to regret will attach a greater importance to sweepstakes' (a) entry conditions, (b) and winning odds.

\subsection{Store Loyalty}

Bloemer \& De Ruyter (1998) defined store loyalty as the biased behavioral response (i.e., revisit), expressed over time, by some decision-making unit with respect to one store out of a set of stores. In many applications, researchers have used different operationalization for this construct such as repetitive purchase frequency or relative purchase amount of the same brand (Tellis, 1988; Brody \& Cunningham, 1968), purchase ratio of the focal store (Cunningham, 1966), purchase probability (Farley, 1964; Massey, Montgomery, \& Morrison, 1970), repeat purchasing behavior (Kahn, Kalwani, \& Morrison, 1986; Brown, 1952), and other aspects of purchasing behavior (Ehrenberg, 1988; DuWors \& Haines, 1990). While these measures concern with behavioral aspects of store loyalty, recent study suggested that attitudinal aspects of store loyalty should be also taken into consideration to better understand the construct (Kamran-Disfani et al., 2017). Dick \& Basu (1994) suggested that both constructs are closely related, where attitudinal loyalty gives rise to behavioral loyalty. However, there could be disconformity between attitudinal and behavioral loyalty; for instance, when repeat purchase behavior is caused by inertia or risk-aversion (Kamran-Disfani et al., 2017). Thus, it is suggested to treat them as different constructs.

Because customers who are behaviorally loyal will purchase more frequently than other customers, it should be easier for them to meet the condition of sweepstakes conducted by the focal store. There is no need to accelerate purchases because they will meet the condition on a regular basis. Thus, it can be expected customers with higher behavioral loyalty will put less importance to sweepstakes entry condition. By contrast, customers who are less loyal may have to purchase more frequently than usual if they want to enter the sweepstakes, forcing them to forgone the opportunity to purchase in other stores. This may reduce their expected utility, which can be compensated by the prize they get from winning the sweepstakes. Thus, we expect disloyal customers concern about the size of sweepstakes prizes when deciding on their participation. In addition, disloyal customers may not prefer sweepstakes that implemented for a shorter period because this will increase the pressure to purchase 
more frequently within a limited time period. Thus we expect their evaluation of sweepstakes attractiveness will be influenced, to a large extent, by the implementation term. Hence,

H3: Subjects with higher behavioral loyalty will attach less importance to sweepstakes' (a) term, (b) entry condition, (c) and prize.

With regard to attitudinal loyalty, studies have shown that this construct is correlated with customer satisfaction (Wallin Andreassen \& Lindestad, 1998; Danaher \& Haddrell, 1996; Taylor \& Baker, 1994). Further, attitudinal loyalty has been shown to be positively associated with repurchase intentions (Yu \& Dean, 2006). Given favorable attitude to a store, customers with higher attitudinal loyalty should be less resistant to sweepstakes promoted by the preferred store, even when the entry conditions are high. Negative association between attitudinal loyalty and price consciousness (Ailawadi, Pauwels, \& Steenkamp, 2008) also provides a rational for this prediction because loyal customers tend to spend higher amount in a focal store. Thus, the decision to enter sweepstakes by customers with higher attitudinal loyalty should be less affected by entry conditions. Furthermore, as loyal customers are likely to be satisfied with a store, this positive experience results in trust of the customers in the store (Singh \& Sirdeshmukh, 2000). This favorable relationships between customers and a store should diminish the disappointment resulted from the failure to get the prize of the sweepstakes. That is, the extent of negative attitudes of loyal customers when failing to win the prize will be smaller than that of disloyal customers. Accordingly, we expect the size of prizes and odds of winning of sweepstakes to be less influential for loyal customers when evaluating sweepstakes attractiveness.

H4: Subjects with higher attitudinal loyalty will attach less importance to sweepstakes' (a) entry condition, (b) prize, (c) and winning odds.

\subsection{Product Characteristics}

In addition to the effects of individual traits, we aim to conduct an exploratory investigation on how customer evaluation of sweepstakes is influenced by product characteristics. In particular, we want to know if there any differences in customer's responses to sweepstakes associated with different product types (goods vs. services) and involvement level (low vs. high). Prior studies suggest that consumer behaviors related to goods and services are different in terms of perceived risk and product variability (Murray \& Schlacter, 1990), quality assessment (Parasuraman, Zeithaml, \& Berry 1985), and response to sales promotions (Wakefield \& Barnes, 1996). Further, studies have shown that product involvement is associated with the extent to which consumers engage in information search (Beatty \& Smith, 1987), accept advertising messages (Petty, Cacioppo, \& Schumann, 1983), and respond to price promotions (Hunt et al., 1995). However, despite the large body of research on these topics, how product type and involvement affect the evaluation of sweepstakes remains unclear. To address this issue, we consider sweepstakes promoted by four retailers selling products that have different characteristics. Table 1 shows the retail formats representing our manipulation of product type and involvement. We manipulated product involvement by choosing retail firms with different expected customer spending per store trip, where higher spending is associated with higher involvement level.

Table 1. The manipulation of product characteristics

\begin{tabular}{|c|c|c|c|}
\hline & & Product involvement & \\
\hline \multirow{3}{*}{$\begin{array}{l}\text { Product } \\
\text { type }\end{array}$} & & Low & High \\
\hline & Goods & Convenience store & Appliance store \\
\hline & Service & Cafe & Travel agency \\
\hline
\end{tabular}

\section{Research Methodology}

We conduct conjoint analysis and multivariate regression analysis to examine the hypothesized effects of the individual traits on the evaluation of sweepstakes attractiveness. First, we estimate individual-level part-worth utilities with respect to the attributes. Subsequently, we calculate the range of each attribute from the corresponding part-worth utility estimates. Finally, treating the ranges as dependent variables, we conduct a multivariate regression analysis to explain their variation across subjects by using individual traits and a number of control variables. In this step, we split the sample according to product characteristics and conduct the analysis for each sub-sample.

Let $U_{i k},(i=1,2, \ldots, I, k=1,2, \ldots, K)$ denote the attractiveness (or utility) of the $k$-th sweepstakes profile for customer $i$. We assume that $U_{i k}$ is determined by the level of the attributes that characterize the profile. 


$$
U_{i k}=\sum_{s=1}^{S} \sum_{t=1}^{T} \beta_{i s t} x_{s t}^{(k)}+\varepsilon_{i k}
$$

Here, $\beta_{i s t}$ refers to the part-worth utility of customer $i$ with respect to the $s$-th level of attribute $t$. In this study, we design the profiles so that all attributes have three levels; for example, low, moderate, and high. Further, $x_{s t}^{(k)}$ represents an indicator which equals $-1,0$, and 1 if profile $k$ contains the "low", "moderate", and "high" level in attribute $t$, respectively. That is, we normalize the part-worth utilities such that those corresponding with the moderate level are set to equal zero. For convenience, we assume that part-worth utilities corresponding to the "low" and "high" levels to have the same magnitudes but with the opposite signs. Letting the error term $\varepsilon_{i k}$ to follow the extreme value distribution, we employ an ordered logit model and estimate the part-worth utilities for each subject by using maximum likelihood method.

Given the estimates of part-worth utilities $\left\{\hat{\beta}_{i s t}\right\}$, we calculate the range with respect to attribute $t$ as $r_{i t}=2\left|\hat{\beta}_{i s t}\right|$ which can be interpreted as the importance attached by customer $i$ to the attribute. Next, let $r_{i}=\left[r_{i 1}, r_{i 2}, \ldots, r_{i T}\right]^{\prime}$ and $x_{i}$ be a vector whose elements are individual trait variables (i.e., rationality, regret, behavioral loyalty, and attitudinal loyalty) and control variables of consumer $i$. The multivariate regression model is expressed as follows.

$$
r_{i}=B x_{i}+e_{i}
$$

Here, $B$ is a coefficients matrix and $e_{i}$ is a vector of error terms which follows a multivariate normal distribution. The parameters in this model are estimated by using generalized maximum likelihood method.

Table 2 illustrates the design of conjoint analysis used in this study. For implementation term, we assign three levels: one month, three mounts, and six months. Likewise, the entry condition has three attribute levels: low, moderate, and high. These attribute levels correspond to different total purchase amounts that can be attained by making as many as one, five, and ten store visits. Thus, the low level is equivalent to average purchase amount in a single visit, which could vary depending on the store where the purchase is made. Further, the levels of prize value are set to 500 yen, 2,500 yen, and 5,000 yen. Finally, we assign low, moderate, and high levels for winning odds attribute reflecting the portion of entrants who eventually win the prizes. Having defined the attribute levels, we subsequently generate an orthogonal design used in this study. This resulted in nine profiles of sweepstakes as shown in Table 3.

Table 2. Conjoint analysis design

\begin{tabular}{ll}
\hline Attribute & Level \\
\hline Term & One month, three months, six months \\
\hline \multirow{3}{*}{ Condition } & Low: The amount attained in a single store visit. \\
& Moderate: The amount attained in approximately five store visits. \\
& High: The amount attained in approximately ten store visits. \\
\hline Prize & 500 yen, 2,500 yen, 5,000 yen \\
\hline & Low: Only a few entrants win the prize by chance. \\
Odds & Moderate: A moderate number of entrants win the prize by chance. \\
& High: All entrants get the prize for sure.
\end{tabular}

Note. The prize amounts are equivalent to 5, 25, and 50 U.S. dollars, respectively.

\begin{tabular}{|c|c|c|c|c|}
\hline Profile & $\begin{array}{l}\text { Attribute } \\
\text { Term }\end{array}$ & Condition & Prize & Odds \\
\hline Profile 1 & Three months & High & 5,000 yen & High \\
\hline Profile 2 & Six months & Moderate & 500 yen & High \\
\hline Profile 3 & Three months & Moderate & 2,500 yen & Low \\
\hline Profile 4 & Six months & Low & 5,000 yen & Low \\
\hline Profile 5 & Three months & Low & 500 yen & Moderate \\
\hline Profile 8 & Six months & High & 2,500 yen & Moderate \\
\hline Profile 9 & One month & Moderate & 5,000 yen & Moderate \\
\hline
\end{tabular}

Table 3. Orthogonal design of sweepstake's profiles 


\section{Data}

\subsection{Data Collection}

We conduct a survey to collect data on consumers' preferences toward the sweepstake's profiles. A number of 350 undergraduate students from a large university in Western Japan participated in the survey conducted between October and November 2016. We assigned the subjects to one of the retail formats and asked them to think of a situation where the stores they patronize were conducting a sweepstake promotion. Subsequently, we showed the subjects all of the profiles and then asked them to rank the profiles according to their preferences. Finally, we asked the subjects to answer a questionnaire regarding their personal traits. The verification of their responses revealed that only 218 of the responses were valid (109 men). Table 4 shows the summary of subjects' individual traits.

Table 4. Summary statistics of individual trait variables

\begin{tabular}{lllllll}
\hline Product characteristics & Individual trait & Mean & Min & Median & Max & SD \\
\hline Goods & Regret & 4.35 & 1.25 & 4.50 & 6.62 & 1.07 \\
$(\mathrm{n}=119)$ & Rationality & 4.74 & 2.00 & 4.75 & 6.25 & 0.83 \\
& Behavioral loyalty & 2.64 & 1.00 & 2.00 & 5.00 & 1.74 \\
& Attitudinal loyalty & 3.46 & 1.50 & 3.50 & 5.00 & 0.66 \\
Service & Regret & 4.29 & 1.00 & 4.37 & 7.00 & 1.16 \\
$(\mathrm{n}=99)$ & Rationality & 4.73 & 2.50 & 4.75 & 7.00 & 0.97 \\
& Behavioral loyalty & 1.80 & 1.00 & 1.00 & 5.00 & 1.23 \\
& Attitudinal loyalty & 3.41 & 2.00 & 3.00 & 5.00 & 0.78 \\
High involvement & Regret & 4.33 & 1.00 & 4.50 & 7.00 & 1.21 \\
$(\mathrm{n}=117)$ & Rationality & 4.65 & 2.00 & 4.75 & 6.75 & 0.81 \\
& Behavioral loyalty & 2.83 & 1.00 & 3.00 & 5.00 & 1.65 \\
& Attitudinal loyalty & 3.57 & 1.00 & 3.50 & 5.00 & 0.72 \\
Low involvement & Regret & 4.31 & 1.62 & 4.37 & 6.75 & 1.00 \\
$(\mathrm{n}=101)$ & Rationality & 4.83 & 2.50 & 4.87 & 7.00 & 0.98 \\
& Behavioral loyalty & 1.60 & 1.00 & 1.00 & 5.00 & 1.20 \\
& Attitudinal loyalty & 3.28 & 1.50 & 3.00 & 5.00 & 0.68 \\
\hline
\end{tabular}

Next, we show the average rank of each profile in Table 5. In all retail formats, we observed that profile 6 [one month, high, 500 yen, low] is the most preferred one, while profile 7 [one month, low, 2,500 yen, high] appears to be the one that perceived as being less attractive than the others.

Table 5. Average ranks of each profile by product characteristics

\begin{tabular}{lllll}
\hline Profile & Goods & Service & Low involvement & High involvement \\
\hline Profile 1 & 3.29 & 3.44 & 3.09 & 3.67 \\
Profile 2 & 4.33 & 4.62 & 4.42 & 4.51 \\
Profile 3 & 5.50 & 5.43 & 5.40 & 5.55 \\
Profile 4 & 4.54 & 4.74 & 4.91 & 4.31 \\
Profile 5 & 5.64 & 5.96 & 5.90 & 5.65 \\
Profile 6 & 7.71 & 7.13 & 7.32 & 7.59 \\
Profile 7 & 2.86 & 2.86 & 2.93 & 2.79 \\
Profile 8 & 6.40 & 6.08 & 6.23 & 6.27 \\
Profile 9 & 4.68 & 4.70 & 4.76 & 4.62 \\
\hline
\end{tabular}

\subsection{Variable Measurement}

We measured rationality, regret, and attitudinal loyalty by using a seven-point Likert scale $(1=$ strongly disagree, $7=$ strongly agree). For rationality and regret, we used the measure proposed by Schwartz et al. (2002). Here, rationality is treated as a construct representing the extent to which a customer is willing to maximize the outcome of his/her decision or behavior. Further, attitudinal loyalty was measured by asking the subjects how they think of and evaluate the focal store (Sirgy et al., 1991). Finally, we simply asked how often they visit the store to measure behavioral loyalty $(1=$ not very often, $5=$ very often $)$. We show the items used to measure the constructs in the Appendix. 


\section{Results}

\subsection{Reliability and Validity Assessment}

To check the reliability and validity of the measures of rationality, regret, and attitudinal loyalty, we first conducted an exploratory factor analysis. We observed that all items converged to the corresponding factors and the extracted factor loadings were greater than 0.5 . We assessed the internal consistency reliability by using the Cronbach alpha and item-to-total correlations. The values of the Cronbach alpha ranged from 0.82 to 0.89 , indicating good internal consistency. Further, the values of item-total correlations ranged from 0.65 to 0.82 which were greater than the recommended value, 0.60 for field studies (Kline, 2000). The convergent validity of the measurement items was examined by factor loadings, composite reliability, and the variance-extracted measure. As for factor loadings, we confirmed that the values were greater than 0.60. Likewise, all the composite reliabilities were greater than 0.80 , and all variance-extracted measure were greater than 0.50 , suggesting convergent validity of the measurement items (Kline, 2000). Finally, we compared the error-adjusted inter-construct correlations with their respective variance extracted measures to test the discriminant validity (Fornell \& Larcker, 1981). The results revealed that all correlations were less than the variance extracted measures of the respective constructs; thus, we confirmed discriminant validity between the constructs.

\subsection{Part-worth Utility, Range, and Attribute Importance}

Table 6 shows the average of the estimates of part-wort utilities. Recall that the estimates are the coefficients of attributes' level dummies taking values of $-1,0$, and 1 for low, moderate, and high levels, respectively. Thus, the estimates of moderate levels must be zero, and the other extreme levels must be of the same magnitude but with the opposite signs. We found the results for sweepstakes term varied among product types and involvement. Subjects assigned to goods and low involvement groups rated sweepstakes with longer implementation period as more favorable, while those belong to service and high involvement groups did the other way around. This implies that consumers prefer long-term to sort-term sweepstakes if the promotions are implemented by a firm selling goods or low involvement product, and vice versa. However, the results for the other attributes appeared to be the same among product types and involvement levels, showing that most of the subjects prefer sweepstakes that have lower entry condition, offer greater prize, and have higher odds of winning.

Table 6. Average estimates of part-worth utilities

\begin{tabular}{llllll}
\hline Attribute & Level & Goods & Service & Low involvement & High involvement \\
\hline \multirow{4}{*}{ Term } & One month & -0.34 & 0.38 & -0.60 & 0.66 \\
& Three months & 0 & 0 & 0 & 0 \\
& Six months & 0.34 & -0.38 & 0.60 & -0.66 \\
\multirow{4}{*}{ Condition } & Low & 5.63 & 2.82 & 4.51 & 4.17 \\
& Moderate & 0 & 0 & 0 & 0 \\
\multirow{4}{*}{ Prize } & High & -5.63 & -2.82 & -4.51 & -4.17 \\
& 500 yen & -4.74 & -2.85 & -4.79 & -2.84 \\
& Odds & 0 & 0 & 0 & 0 \\
& 5,, 000 yen & 4.74 & 3.62 & 4.79 & 2.84 \\
& Low & -6.09 & -6.39 & -4.95 & -7.71 \\
& Moderate & 0 & 0 & 0 & 0 \\
& High & 6.09 & 6.39 & 4.95 & 7.71 \\
\hline
\end{tabular}

Table 7 shows the average range and importance of each sweepstake attribute. We found that winning odds was rated as the most important attribute, implying that the likelihood of winning the prize has the largest effect on consumer decision to participate in a sweepstake. The next important attribute is entry condition, indicating that lowering entry thresholds will considerably increase customer evaluation. It is also interesting to observe that the size of prize was ranked below entry condition, indicating that average people find it to be less influential than winning odds and entry condition. Additionally, implementation term appeared to be the least important attribute with its importance ranges from $18.98 \%$ to $19.94 \%$. 
Table 7. Attribute utility range and importance

\begin{tabular}{|c|c|c|c|c|c|}
\hline Attribute & $\begin{array}{l}\text { Range } \\
\text { Importance }\end{array}$ & Goods & Service & Low involvement & High involvement \\
\hline \multirow{2}{*}{ Term } & Range & 12.95 & 12.24 & 12.95 & 12.25 \\
\hline & Importance & $18.98 \%$ & $19.94 \%$ & $19.60 \%$ & $19.13 \%$ \\
\hline \multirow{2}{*}{ Condition } & Range & 17.53 & 13.91 & 15.74 & 16.06 \\
\hline & Importance & $25.69 \%$ & $22.67 \%$ & $23.82 \%$ & $25.09 \%$ \\
\hline \multirow{2}{*}{ Prize } & Range & 15.44 & 12.51 & 14.63 & 13.51 \\
\hline & Importance & $22.63 \%$ & $20.38 \%$ & $22.14 \%$ & $21.10 \%$ \\
\hline \multirow{2}{*}{ Odds } & Range & 22.31 & 22.72 & 22.75 & 22.20 \\
\hline & Importance & $32.70 \%$ & $37.01 \%$ & $34.44 \%$ & $34.68 \%$ \\
\hline
\end{tabular}

\subsection{Individual Trait Effects}

Next, we examine the effect of personal traits on how customers attach importance to sweepstakes' attributes. Table 8 shows the results of multivariate regression analysis for different product types. Except for attitudinal loyalty, we found that all coefficients of the individual traits were not significant for the case of retailers selling goods. While significant, the effect of attitudinal loyalty on winning odds was negative, leading to the rejection of H4(c). Thus, for sweepstakes associated with goods, we rejected all of our hypotheses. Similarly, in case of sweepstakes promoted by service providers, the effect of regret on entry condition and winning odds were insignificant, leading to the rejection of $\mathrm{H} 2$ (a) and $\mathrm{H} 2(\mathrm{~b})$. However, the effect of rationality on implementation term was significant with the expected sign, providing support for H1(a). Likewise, its effect on winning odds was also significant, in support of H1(c). In addition, we also found significant effects of behavioral loyalty on sweepstake's term and condition with the expected signs; therefore, H3(a) and H3(b) were supported.

Table 8. Estimates of multivariate regression model for different product types

\begin{tabular}{|c|c|c|c|c|c|c|c|c|}
\hline & \multicolumn{4}{|l|}{ Goods } & \multicolumn{4}{|c|}{ Service } \\
\hline & Term & Condition & Prize & Odds & Term & Condition & Prize & Odds \\
\hline \multirow{2}{*}{ (Intercept) } & 16.05 & 31.00 & 31.66 & -0.34 & 18.77 & 17.52 & 12.75 & 10.40 \\
\hline & (10.34) & (12.43) & (10.99) & (15.5) & (8.53) & (11.89) & $(9.81)$ & (16.39) \\
\hline \multirow{2}{*}{ Gender } & -0.08 & 0.67 & 0.54 & 4.60 & -0.19 & 3.57 & -2.94 & -6.44 \\
\hline & $(2.54)$ & $(3.05)$ & $(2.70)$ & (3.82) & $(2.24)$ & (3.12) & $(2.58)$ & $(4.31)$ \\
\hline \multirow{2}{*}{ Experience } & -0.02 & 1.57 & 0.20 & 0.71 & 0.03 & 1.06 & 0.54 & 0.49 \\
\hline & $(0.96)$ & (1.15) & (1.02) & (1.44) & $(0.78)$ & (1.08) & $(0.89)$ & (1.49) \\
\hline \multirow{2}{*}{ Regret } & 0.45 & -0.57 & 0.71 & 2.34 & -3.38 & -1.77 & 0.43 & -2.47 \\
\hline & $(1.28)$ & (1.54) & $(1.36)$ & (1.93) & (1.03) & $(1.43)$ & (1.18) & (1.98) \\
\hline \multirow{2}{*}{ Rationality } & -1.60 & -1.01 & -1.55 & -3.55 & 2.18 & 0.74 & 0.40 & 7.53 \\
\hline & $(1.65)$ & (1.98) & $(1.75)$ & $(2.48)$ & (1.22) & $(1.70)$ & $(1.40)$ & (2.34) \\
\hline \multirow{2}{*}{ Behavioral loyalty } & 1.15 & 0.27 & -0.54 & -0.93 & -2.19 & -2.66 & -1.13 & 1.94 \\
\hline & $(0.74)$ & $(0.89)$ & $(0.79)$ & (1.12) & (1.08) & (1.50) & $(1.24)$ & (2.07) \\
\hline \multirow{2}{*}{ Attitudinal loyalty } & -0.12 & -3.81 & -3.33 & 7.69 & 0.46 & -0.06 & -0.76 & -4.41 \\
\hline & (1.99) & $(2.39)$ & $(2.11)$ & (2.99) & (1.62) & $(2.26)$ & (1.87) & (3.12) \\
\hline
\end{tabular}

Note. Bold fonts indicate significant estimates at $\alpha=0.05$. Numbers in parentheses are standard errors.

Table 9 shows the results of multivariate regression analysis for different involvement level. For low involvement group, rationality appeared to have negative significant effect on term attribute, implying that rational consumers attach less importance to this attribute. This is in contradiction to what we have predicted, leading to the rejection of H1(a). Further, for the effects of regret and behavioral loyalty, the estimates were not significant for all sweepstakes' attributes, resulted in the rejection of $\mathrm{H} 2$ and $\mathrm{H} 3$. However, we found the effects of attitudinal loyalty were negative and significant on condition and prize attributes, in support of H4(a) and H4(b). Thus, we confirmed that entry condition and winning prize will be less influential for consumers who have positive attitudes toward stores to enter sweepstakes. For the results of sweepstakes carried out by stores selling expensive products (i.e., high involvement), we found the effect of regret on winning odds was negative and significant. Having predicted the direction to be positive, we rejected H2(b). By contrast, the effect of rationality on the same attribute was positive and significant, providing a support for H1(c). Further, behavioral loyalty exhibited significant negative effect on prize attribute, which is consistent with our hypothesis. Thus, we have a support for $\mathrm{H} 3(\mathrm{c})$. Additionally, the results for attitudinal loyalty revealed that its effects were not 
significant for all sweepstakes' attributes, leading to the rejection of the corresponding hypotheses. We summarize the hypotheses testing results in Table 10.

Table 9. Estimates of multivariate regression analysis for different involvement level

\begin{tabular}{|c|c|c|c|c|c|c|c|c|}
\hline & \multicolumn{4}{|c|}{ Low involvement } & \multicolumn{4}{|c|}{ High involvement } \\
\hline & Term & Condition & Prize & Odds & Term & Condition & Prize & Odds \\
\hline (Intercept) & $\begin{array}{l}21.45 \\
(8.62)\end{array}$ & $\begin{array}{l}20.27 \\
(11.05)\end{array}$ & $\begin{array}{l}23.16 \\
(10.90)\end{array}$ & $\begin{array}{l}20.27 \\
(16.26)\end{array}$ & $\begin{array}{l}18.18 \\
(10.96)\end{array}$ & $\begin{array}{l}26.08 \\
(14.09)\end{array}$ & $\begin{array}{l}24.42 \\
(10.28)\end{array}$ & $\begin{array}{l}1.20 \\
(16.87)\end{array}$ \\
\hline Gender & $\begin{array}{l}-0.08 \\
(2.07)\end{array}$ & $\begin{array}{l}0.80 \\
(2.66)\end{array}$ & $\begin{array}{l}1.11 \\
(2.62)\end{array}$ & $\begin{array}{l}-3.31 \\
(3.91)\end{array}$ & $\begin{array}{l}-0.43 \\
(2.86)\end{array}$ & $\begin{array}{l}4.82 \\
(3.68)\end{array}$ & $\begin{array}{l}-2.59 \\
(2.68)\end{array}$ & $\begin{array}{l}2.98 \\
(4.40)\end{array}$ \\
\hline Experience & $\begin{array}{l}-0.61 \\
(0.67)\end{array}$ & $\begin{array}{l}1.80 \\
(0.87)\end{array}$ & $\begin{array}{l}-0.02 \\
(0.85)\end{array}$ & $\begin{array}{l}-1.23 \\
(1.28)\end{array}$ & $\begin{array}{l}1.74 \\
(1.17)\end{array}$ & $\begin{array}{l}0.46 \\
(1.50)\end{array}$ & $\begin{array}{l}1.10 \\
(1.10)\end{array}$ & $\begin{array}{l}3.29 \\
(1.80)\end{array}$ \\
\hline Regret & $\begin{array}{l}1.16 \\
(1.00)\end{array}$ & $\begin{array}{l}-0.65 \\
(1.28)\end{array}$ & $\begin{array}{l}1.66 \\
(1.26)\end{array}$ & $\begin{array}{l}3.63 \\
(1.89)\end{array}$ & $\begin{array}{l}-3.85 \\
(1.42)\end{array}$ & $\begin{array}{l}-1.93 \\
(1.83)\end{array}$ & $\begin{array}{l}-0.98 \\
(1.33)\end{array}$ & $\begin{array}{l}-4.09 \\
(2.19)\end{array}$ \\
\hline Rationality & $\begin{array}{l}-2.57 \\
(1.49)\end{array}$ & $\begin{array}{l}0.65 \\
(1.91)\end{array}$ & $\begin{array}{l}-0.46 \\
(1.88)\end{array}$ & $\begin{array}{l}-2.18 \\
(2.81)\end{array}$ & $\begin{array}{l}2.36 \\
(1.48)\end{array}$ & $\begin{array}{l}-0.78 \\
(1.90)\end{array}$ & $\begin{array}{l}-0.89 \\
(1.39)\end{array}$ & $\begin{array}{l}4.22 \\
(2.28)\end{array}$ \\
\hline Behavioral loyalty & $\begin{array}{l}0.33 \\
(0.64)\end{array}$ & $\begin{array}{l}0.48 \\
(0.82)\end{array}$ & $\begin{array}{l}0.11 \\
(0.81)\end{array}$ & $\begin{array}{l}0.34 \\
(1.20)\end{array}$ & $\begin{array}{l}1.42 \\
(1.29)\end{array}$ & $\begin{array}{l}-1.81 \\
(1.66)\end{array}$ & $\begin{array}{l}-2.34 \\
(1.21)\end{array}$ & $\begin{array}{l}-0.70 \\
(1.99)\end{array}$ \\
\hline Attitudinal loyalty & $\begin{array}{l}-0.07 \\
(1.45)\end{array}$ & $\begin{array}{l}-3.68 \\
(1.86)\end{array}$ & $\begin{array}{l}-4.02 \\
(1.84)\end{array}$ & $\begin{array}{l}0.61 \\
(2.74)\end{array}$ & $\begin{array}{l}-2.83 \\
(2.32)\end{array}$ & $\begin{array}{l}0.34 \\
(2.98)\end{array}$ & $\begin{array}{l}-0.47 \\
(2.18)\end{array}$ & $\begin{array}{l}1.72 \\
(3.57)\end{array}$ \\
\hline
\end{tabular}

Note. Bold fonts indicate significant estimates at $\alpha=0.05$. Numbers in parentheses are standard errors.

Table 10. Summary of hypotheses testing results

\begin{tabular}{|c|c|c|c|c|c|c|c|}
\hline \multirow{2}{*}{ Hypothesis } & \multirow{2}{*}{ Individual trait } & \multirow{2}{*}{ Attribute } & \multirow{2}{*}{$\begin{array}{l}\text { Expected } \\
\text { direction }\end{array}$} & \multicolumn{4}{|c|}{ Result } \\
\hline & & & & Goods & Service & Low involvement & High involvement \\
\hline $\mathrm{Hl}(\mathrm{a})$ & Rationality & Term & Positive & Not supported & Supported & Not supported & Not supported \\
\hline $\mathrm{Hl}(\mathrm{b})$ & Rationality & Prize & Positive & Not supported & Not supported & Not supported & Not supported \\
\hline $\mathrm{H} 1(\mathrm{c})$ & Rationality & Odds & Positive & Not supported & Supported & Not supported & Supported \\
\hline $\mathrm{H} 2(\mathrm{a})$ & Regret & Condition & Positive & Not supported & Not supported & Not supported & Not supported \\
\hline $\mathrm{H} 2(\mathrm{~b})$ & Regret & Odds & Positive & Not supported & Not supported & Not supported & Not supported \\
\hline $\mathrm{H} 3(\mathbf{a})$ & Behavioral loyalty & Term & Negative & Not supported & Supported & Not supported & Not supported \\
\hline $\mathrm{H} 3(\mathrm{~b})$ & Behavioral loyalty & Condition & Negative & Not supported & Not supported & Not supported & Not supported \\
\hline $\mathrm{H} 3(\mathrm{c})$ & Behavioral loyalty & Prize & Negative & Not supported & Supported & Not supported & Supported \\
\hline $\mathrm{H} 4(\mathrm{a})$ & Attitudinal loyalty & Condition & Negative & Not supported & Not supported & Supported & Not supported \\
\hline $\mathrm{H} 4(\mathrm{~b})$ & Attitudinal loyalty & Prize & Negative & Not supported & Not supported & Supported & Not supported \\
\hline $\mathrm{H} 4(\mathrm{c})$ & Attitudinal loyalty & Odds & Negative & Not supported & Not supported & Not supported & Not supported \\
\hline
\end{tabular}

\section{Discussion and Implications}

\subsection{Discussion}

In this study, we addressed the questions of how individual traits affect customer evaluation of sweepstakes' attractiveness and how these effects are moderated by product type and involvement. We assumed that customer evaluation depends on four key attributes: sweepstake's term, entry condition, prize, and winning odds. The results of the conjoint analysis revealed that sweepstakes' attractiveness is associated positively with the size of the prizes and the odds of winning, and associated negatively with entry condition. However, we observed that the effect of sweepstake's term was different for different product types and involvement levels. For sweepstakes associated with goods or low involvement product, a longer implementation term resulted in more favorable evaluation. By contrast, the subjects rated short-term sweepstakes as more favorable for service and high-involvement categories. We conjecture that for low involvement categories, customers might perceive that they need to make multiple visits to a store in order to meet entry conditions because of low purchase amount in each store visit.

Further, the calculation of attribute ranges indicated that average customers consider winning odds as the most important attribute, implying that the decision of whether to enter a sweepstake is largely determined by how 
likely they would get the prizes. The next attribute to which customers attach considerable importance is entry condition; with a higher entry condition leads to a decline in sweepstake evaluation. In addition, for prize and term attributes, although less important, the results suggested that their influences cannot be ignored.

The results from multivariate regression analysis revealed that the roles of individual traits in influencing customer evaluation of sweepstakes vary across product types and involvement level. For sweepstakes promoted by firms selling goods, we found the effects of rationality, regret, and store loyalty are not significant. However, for service category, it is shown that rationality is positively associated with the importance customers attach on sweepstakes' term and winning odds. Thus, we concluded that rational customers are likely to participate in sweepstakes held by service providers in shorter time period and impose greater probability of winning. We also found that behavioral loyalty is negatively associated with term and prize attributes. However, this does not mean that loyal customers do not account for sweepstake's term and prizes; rather, it should be interpreted that disloyal customers attach importance to these attributes more than loyal customers do.

With regard to involvement level, we found significant effects of attitudinal loyalty on the ranges of entry condition and prize attributes. The directions of both effects were negative, indicating that the ease to enter and the size of the prizes are factors influencing those who have less favorable attitude toward the stores when evaluating sweepstakes. For high-involvement context, rationality appeared to have significant effect on winning odds attribute, indicating that rational customers' evaluation of sweepstake's attractiveness is affected largely by the chance of winning the prize. Thus, rational customers would be less likely to enter a sweepstake if it provides prizes in small amount. Further, we also found behavioral loyalty have significant effect on prize attribute, with a negative sign as expected. This result implies that customers who visit a store less frequently would not enter a sweepstake held by the store unless they perceive that the prize is high enough.

\subsection{Implications}

The investigation of how individual traits affect customers' evaluation of sweepstakes is still sparse. In this study we aimed to elucidate the roles of customers' rationality, regret, behavioral and attitudinal loyalty in governing the way customers attach importance to sweepstake's attributes, and examine the ultimate effects of these constructs on the perception of sweepstake's attractiveness. We found that the evaluations appeared to depend on the type of product category and involvement. While we found that the effects of individual traits were not significant for sweepstakes held by the firms selling goods, it is shown that rationality and behavioral loyalty were significant for sweepstakes held by service providers. The results suggested that service providers should properly design their sweepstakes strategy to meet customers' expectations, given their sweepstakes' objectives and budget constraints. For example, if the firms know that most of their target customers are rational, they may undertake sweepstakes in a shorter time period with higher odds of winning, provided that sweepstakes' evaluation by rational customers are likely to hinge on the implementation period and odds of winning. Likewise, if the sweepstakes are targeted at less loyal customers to encourage them to repurchase, a short-term term sweepstake with grand prizes would attract these customers to enter because these attributes are critical in their evaluations.

Additionally, for low involvement products, the effects of attitudinal loyalty on entry condition and prize were shown to be significant. Thus, for firms selling inexpensive products, conducting sweepstakes with lower entry conditions and higher prizes would attract those who have less favorable attitudes toward the firms. This is an important finding of this study, given that turning less loyal customers to be loyal customers has been a central issue in relationship marketing. Finally, for high involvement product, this study provided evidence of the effect of rationality on winning odds, and the effect of behavioral loyalty on prize attribute. Accordingly, increasing the level of these attributes should be effective for attracting customers to participate in a sweepstake when they consider buying high involvement products.

\section{Conclusion}

Sweepstake is one of promotion tools that can be used to improve customer loyalty by encouraging repurchase behavior. To attract as many as customers to enter in a sweepstake, a marketer should understand the factors influencing its evaluation by customers. Further, it is also important to know how the evaluation is affected by individual traits and product characteristics. A better understanding of this issue should be useful to address the questions how retail firms should design an effective sweepstake as well as at whom it should be targeted. In this study, we investigated how sweepstakes' attractiveness is determined by implementation term, entry condition, prize amount, and odds of winning, and subsequently examined how customers evaluation of these attributes are affected by individual traits and product characteristics. The results from the conjoint analysis and multivariate regression analysis revealed that all attributes under consideration significantly affect sweepstakes' attractiveness, 
and the effects of individual characteristics appeared to be moderated by product characteristics. The findings provide new insights into the roles of customer and product heterogeneity in the effectiveness of sweepstakes. Further, the results also useful to design an effective sweepstake targeted at a specific customer segment.

Despite its contribution, we note some limitations in this study. Our data were collected from undergraduate students which may not represent the whole customer population. We recognize potential bias stems from the fact that subjects in our sample may have limited experiences with sweepstakes. Thus, sampling from a wider population should improve the quality of data. Second, we focused our study on four store formats (i.e., convenience store, cafe, appliance shop, and travel agency) which can give rise to an issue of generalizability. Therefore, further research using data from different store formats is needed to check whether our findings hold in general. Finally, while customers would consider several stores in which they make purchases, we did not account for the influence of competitors in our framework. Future research could address this issue by allowing customer decision to enter sweepstakes to be affected by competing stores in addition to the focal store.

\section{Acknowledgments}

This research was supported by JSPS KAKENHI [grant number A26285095a]. All authors contributed equally to the study.

\section{References}

Ailawadi, K. L., Pauwels, K., \& Steenkamp, J. B. E. (2008). Private-label use and store loyalty. Journal of Marketing, 72(6), 19-30. https://doi.org/10.1509/jmkg.72.6.19

Alba, J. W., Mela, C. F., Shimp, T. A., \& Urbany, J. E. (1999). The effect of discount frequency and depth on consumer price judgments. Journal of Consumer Research, 26(2), 99-114. https://doi.org/10.1086/209553

Arcidiacono, D. (2011). Consumer rationality in a multidisciplinary perspective. The Journal of SocioEconomics, 40(5), 516-522. https://doi.org/10.1016/j.socec.2011.01.003

Beatty, S. E., \& Smith, S. M. (1987). External search effort: An investigation across several product categories. Journal of Consumer Research, 14(1), 83-95. https://doi.org/10.1086/209095

Bell, D. E. (1982). Regret in decision making under uncertainty. Operation Research, 30, 961-998. https://doi.org/10.1287/opre.30.5.961

Blattberg, R. C., Briesch, R., \& Fox, E. J. (1995). How promotions work. Marketing Science, 14(3), G122-G132. https://doi.org/10.1287/mksc.14.3.G122

Blattberg, R. C., Kim B. D., \& Neslin S. A. (2008). Database Marketing: Analyzing and Managing Customers. New York: Springer.

Bloemer, J., \& De Ruyter, K. (1998). On the relationship between store image, store satisfaction and store loyalty. European Journal of Marketing, 32(5/6), 499-513. https://doi.org/10.1108/03090569810216118

Bolton, R. N., Kannan, P. K., \& Bramlett, M. D. (2000). Implications of loyalty program membership and service experiences for customer retention and value. Journal of the Academy of Marketing Science, 28(1), 95-108. http://dx.doi.org/10.1177\%2F0092070300281009

Brody, R. P., \& Cunningham, S. M. (1968). Personality variables and the consumer decision process. Journal of Marketing Research, 50-57. https://doi.org/10.2307/3149793

Brown, G. H. (1953). Brand Loyalty-fact of fiction. Advertising Age, 23, 53-55.

Chew, S. H., \& Tan, G. (2005). The market for sweepstakes. The Review of Economic Studies, 72(4), 1009-1029. https://doi.org/10.1111/0034-6527.00359

Cunningham, R. M. (1956). Brand loyalty-what, where, how much. Harvard Business Review, 34(1), 116-128.

Danaher, P. J., \& Haddrell, V. (1996). A comparison of question scales used for measuring customer satisfaction. International Journal of Service Industry Management, 7(4), 4-26. https://doi.org/10.1108/09564239610129922

Dick, A. S., \& Basu, K. (1994). Customer loyalty: toward an integrated conceptual framework. Journal of the Academy of Marketing Science, 22(2), 99-113. http://dx.doi.org/10.1177\%2F0092070394222001

Dowling, G. R., \& Uncles, M. (1997). Do customer loyalty programs really work?. Sloan Management Review, 38(4), 71-82.

DuWors Jr, R. E., \& Haines Jr, G. H. (1990). Event history analysis measures of brand loyalty. Journal of 
Marketing Research, 27(4), 485-493. https://doi.org/10.2307/3172633

Ehrenberg A. S. C. (1988). Repeat Buying: Theory and Applications (2nd ed.). London: Charles. Griffin \& Co.

Farley, J. U. (1964). Why does "Brand Loyalty" vary over products?. Journal of Marketing Research, 1, 9-14. https://doi.org/10.2307/3150371

Fornell, C., \& Larcker D. F. (1981). Evaluating structural equation models with unobservable variables and measurement error. Journal of Marketing Research, 18(1), 39-50. https://doi.org/10.2307/3151312

Huff, L. C., \& Alden, D. L. (1999). An investigation of consumer response to sales promotions in developing markets: A three-country Analysis. Journal of Advertising Research, 38(3), 47-54.

Hunt, K. A., Keaveney, S. M., \& Lee, M. (1995). Involvement, attributions, and consumer responses to rebates. Journal of Business and Psychology, 9(3), 273-297. https://doi.org/10.1007/BF02230970

Inman, J. J., Dyer, J. S., \& Jia, J. (1997). A generalized utility model of disappointment and regret effects on post-choice valuation. Marketing Science, 16(2), 97-111. https://doi.org/10.1287/mksc.16.2.97

Kahn, B. E., Kalwani, M. U., \& Morrison, D. G. (1986). Measuring variety-seeking and reinforcement behaviors using panel data. Journal of Marketing Research, 23(2), 89-100. https://doi.org/ 10.2307/3151656

Kahneman, D., \& Tversky, A. (1979). Prospect theory: An analysis of decision under risk. Econometrica: Journal of the Econometric Society, 47(2), 263-291. https://doi.org/10.2307/1914185

Kalra, A., \& Shi, M. (2010). Consumer value-maximizing sweepstakes and contests. Journal of Marketing Research, 47(2), 287-300. https://doi.org/10.1509/jmkr.47.2.287

Kamran-Disfani, O., Mantrala, M. K., Izquierdo-Yusta, A., \& Martínez-Ruiz, M. P. (2017). The impact of retail store format on the satisfaction-loyalty link: An empirical investigation. Journal of Business Research, 77, 14-22. https://doi.org/10.1016/j.jbusres.2017.04.004

Kivetz, R., \& Simonson, I. (2002). Earning the right to indulge: Effort as a determinant of customer preferences toward frequency program rewards. Journal of Marketing Research, 39(2), 155-170. https://doi.org/10.1509/jmkr.39.2.155.19084

Kivetz, R., \& Simonson, I. (2003). The idiosyncratic fit heuristic: Effort advantage as a determinant of consumer response to loyalty programs. Journal of Marketing Research, 40(4), 454-467. https://doi.org/10.1509/jmkr.40.4.454.19383

Kivetz, R., Urminsky, O., \& Zheng, Y. (2006). The goal-gradient hypothesis resurrected: Purchase acceleration, illusionary goal progress, and customer retention. Journal of Marketing Research, 43(1), 39-58. https://doi.org/10.1509/jmkr.43.1.39

Kline, P. (2000). The handbook of psychological testing (2nd ed.). London: Routledge.

Kumar, V., \& Reinartz, W. (2012). Customer relationship management: Concept, strategy, and tools. Berlin: Springer Science \& Business Media. https://doi.org/10.1007/978-3-642-20110-3

Kumar, V., \& Shah, D. (2004). Building and sustaining profitable customer loyalty for the 21 st century. Journal of Retailing, 80(4), 317-329. https://doi.org/10.1016/j.jretai.2004.10.007

Kurhade, M., \& Wankhade, R. (2016). An overview on decision making under risk and uncertainty. International Journal of Science and Research, 5(4), 416-422. Retrieved from https://www.ijsr.net/archive/v5i4/v5i4.php

Lewis, M. (2004). The influence of loyalty programs and short-term promotions on customer retention. Journal of Marketing Research, 41(3), 281-292. https://doi.org/10.1509/jmkr.41.3.281.35986

Loomes, G., \& Sugden, R. (1982). Regret theory: An alternative theory of rational choice under uncertainty. The Economic Journal, 92(368), 805-824. https://doi.org/10.2307/2232669

Malhotra, D., Loewenstein, G., \& O'donoghue, T. (2002). Time discounting and time preference: A critical review. Journal of Economic Literature, 40(2), 351-401.

Massey, W. F., Montgomery, D. B., \& Morrison, D. G. (1970). Stochastic models of buyer behavior. Cambridge: MIT Press.

Mazumdar, T., Raj, S. P., \& Sinha, I. (2005). Reference price research: Review and propositions. Journal of Marketing, 69(4), 84-102. https://doi.org/10.1509/jmkg.2005.69.4.84

McDaniel, S. R. (2002). Investigating the roles of gambling interest and impulsive sensation seeking on consumer enjoyment of promotional games. Social Behavior and Personality: An International Journal, 
30(1), 53-64. https://doi.org/10.2224/sbp.2002.30.1.53

Mittal, B., \& Lassar, W. M. (1998). Why do customers switch? The dynamics of satisfaction versus loyalty. Journal of Services Marketing, 12(3), 177-194. https://doi.org/10.1108/08876049810219502

Murray, K. B., \& Schlacter, J. L. (1990). The impact of services versus goods on consumers' assessment of perceived risk and variability. Journal of the Academy of Marketing Science, 18(1), 51-65. https://doi.org/10.1007/BF02729762

Narayana, C. L., \& Raju, P. S. (1985). Gifts versus sweepstakes: Consumer choices and profiles. Journal of Advertising, 14(1), 50-53. http://dx.doi.org/10.1080/00913367.1985.10672930

Parasuraman, A., Zeithaml, V. A., \& Berry, L. L. (1985). A conceptual model of service quality and its implications for future research. Journal of Marketing, 41-50. https://doi.org/10.2307/1251430

Petty, R. E., Cacioppo, J. T., \& Schumann, D. (1983). Central and peripheral routes to advertising effectiveness: The moderating role of involvement. Journal of Consumer Research, 10(2), 135-146. https://doi.org/10.1086/208954

Rigby, D. K., \& Ledingham, D. (2004). CRM done right. Harvard Business Review, 82(11), 118-130.

Roehm, M. L., Pullins, E. B., \& Roehm Jr, H. A. (2002). Designing loyalty-building programs for packaged goods brands. Journal of Marketing Research, 39(2), 202-213. https://doi.org/10.1509/jmkr.39.2.202.19085

Rothchild, M. L., \& Gaidis, W. C. (1981). Behavioral learning theory: Its relevance to marketing and promotion. Journal of Marketing, 45(2), 70-78. https://doi.org/10.2307/1251666

Savage, L. J. (1951). The theory of statistical decision. Journal of the American Statistical Association, 46(253), 55-67.

Schwartz, B., Ward, A., Monterosso, J., Lyubomirsky, S., White, K., \& Lehman, D. R. (2002). Maximizing versus satisficing: happiness is a matter of choice. Journal of Personality and Social Psychology, 83(5), 1178.

Sharp, B., \& Sharp, A. (1997). Loyalty programs and their impact on repeat-purchase loyalty patterns. International Journal of Research in Marketing, 14(5), 473-486. https://doi.org/10.1016/S0167-8116(97)00022-0

Simonson, I. (1992). The influence of anticipating regret and responsibility on purchase decisions. Journal of Consumer Research, 19(1), 105-118. https://doi.org/10.1086/209290

Singh, J., \& Sirdeshmukh, D. (2000). Agency and trust mechanisms in consumer satisfaction and loyalty judgments. Journal of the Academy of Marketing Science, 28(1), 150-167. http://dx.doi.org/10.1177\%2F0092070300281014

Sirgy, M. J., Johar, J. S., Samli, A. C., \& Claiborne, C. B. (1991). Self-congruity versus functional congruity: Predictors of consumer behavior. Journal of the Academy of Marketing Science, 19(4), 363-375. http://dx.doi.org/10.1177\%2F009207039101900409

Taylor, G. A., \& Neslin, S. A. (2005). The current and future sales impact of a retail frequency reward program. Journal of Retailing, 81(4), 293-305. https://doi.org/10.1016/j.jretai.2004.11.004

Taylor, K. (1997). A regret theory approach to assessing consumer satisfaction. Marketing Letters, 8(2), 229-238. https://doi.org/10.1023/A:1007966621364

Taylor, S. A., \& Baker, T. L. (1994). An assessment of the relationship between service quality and customer satisfaction in the formation of consumers' purchase intentions. Journal of Retailing, 70(2), 163-178. https://doi.org/10.1016/0022-4359(94)90013-2

Tellis, G. J. (1988). Advertising exposure, loyalty and brand purchase: A two stage model of choice. Journal of Marketing Research, 15(2) (May), 134-144. https://doi.org/10.2307/3172645

Tsiros, M., \& Mittal, V. (2000). Regret: A model of its antecedents and consequences in consumer decision making. Journal of Consumer Research, 26(4), 401-417. https://doi.org/10.1086/209571

Uncles, M. D., Dowling, G. R., \& Hammond, K. (2003). Customer loyalty and customer loyalty programs. Journal of Consumer Marketing, 20(4), 294-316. https://doi.org/10.1108/07363760310483676

Von Neumann, J., \& Morgenstern, O. (1947). Theory of games and economic behavior (2nd ed). Princeton, NJ: Princeton University Press. 
Wakefield, K. L., \& Barnes, J. H. (1996). Retailing hedonic consumption: a model of sales promotion of a leisure service. Journal of Retailing, 72(4), 409-427. https://doi.org/10.1016/S0022-4359(96)90021-4

Wallin Andreassen, T., \& Lindestad, B. (1998). Customer loyalty and complex services: The impact of corporate image on quality, customer satisfaction and loyalty for customers with varying degrees of service expertise. $\begin{array}{lllll}\text { International Journal of Service Industry Management, } & 9(1), & \text { 7-23. }\end{array}$ https://doi.org/10.1108/09564239810199923

Yi, Y., \& Jeon, H. (2003). Effects of loyalty programs on value perception, program loyalty, and brand loyalty. Journal of the Academy of Marketing Science, 31(3), 229-240. http://dx.doi.org/10.1177\%2F0092070303031003002

Yu, Y. T., \& Dean, A. (2001). The contribution of emotional satisfaction to consumer loyalty. International Journal of Service Industry Management, 12(3), 234-250. https://doi.org/10.1108/09564230110393239

Zeelenberg, M., \& Pieters, R. (2007). A theory of regret regulation 1.0. Journal of Consumer Psychology, 17(1), 3-18. https://doi.org/10.1207/s15327663jcp1701_3

Zeelenberg, M., Van Dijk, W. W., SR Manstead, A., \& der Pligt, J. (1998). The experience of regret and disappointment. Cognition \& Emotion, 12(2), 221-230. http://dx.doi.org/10.1080/026999398379727

\section{Appendix A}

\section{The Measurement of Regret and Rationality Constructs}

Table A. The list of items used to measure regret and rationality

\begin{tabular}{llrl}
\hline Measure & Item & Mean & SD \\
\hline Regret & Whenever I make a choice, I'm curious about what would have happened if I had chosen differently. & 4.413 & 1.581 \\
& Whenever I make a choice, I try to get information about how the other alternatives turned out. & 4.275 & 1.561 \\
& If I make a choice and it turns out well, I still feel like something of a failure if I find out that another & 3.509 & 1.536 \\
& choice would have turned out better. & & \\
& When I think about how I'm doing in life, I often assess opportunities I have passed up. & 3.404 & 1.595 \\
& When I think about how I'm doing in life, I often assess opportunities I have passed up. & 5.005 & 1.522 \\
\hline Rationality & No matter what I do, I have the highest standards for myself. & 4.734 & 1.497 \\
& I treat relationships like clothing: I expect to try a lot on before I get the perfect fit. & 5.303 & 1.230 \\
& When shopping, I have hard time finding clothing that I really love. & 4.798 & 1.298 \\
& When I watch TV, I channel surf, often scanning through the available options even while attempting & 4.642 & 1.703 \\
& to watch one program. & 4.862 & 1.443 \\
& I never settle for second best. & 4.908 & 1.317 \\
& I often find it difficult to shop for a gift for a friend. & 4.619 & 1.791 \\
When I am in the car listening to the radio, I often check other stations to see if something better is & 4919 \\
& playing, even if I'm relatively satisfied with what I'm listening to. & 4.032 & 1.463 \\
\hline
\end{tabular}

\section{Copyrights}

Copyright for this article is retained by the author, with first publication rights granted to the journal.

This is an open-access article distributed under the terms and conditions of the Creative Commons Attribution license (http://creativecommons.org/licenses/by/4.0/). 